Reprod. Nutr. Dévelop., 1986, 26 (6), 1289-1293.

\title{
Immuno-neutralization of maternal plasma oestradiol stimulates fetal growth in rats
}

\author{
G. S. G. SPENCER ( $\left.{ }^{1}\right)$, Kathy G. HALLETT, Angela SEDDON, B. A. MORRIS (*) \\ Animal Physiology Division, ARC Meat Research Institute, \\ Langford, Bristol, BS18 7DY, Avon, UK \\ $\left(^{*}\right)$ Dept. of Biochemistry, University of Surrey, \\ Guildford, GU2 $5 \times H, \cup K$
}

Summary. On day 12 of pregnancy, 7 rats were injected with $2 \mathrm{ml}$ of an anti-oestradiol antiserum a quantity capable of binding $2.4 \mu \mathrm{g}$ oestradiol. Seven further (control) rats were injected with an antiserum raised against human serum globulin. After sacrifice on day 21 of pregnancy, the fetuses from treated rats showed an increase in both placental weight $(0.851 \pm 0.023 \mathrm{~g}, \mathrm{n}=98$ vs $0.752 \pm 0.019 \mathrm{~g}, \mathrm{n}=97)$ and fetal weight $(4.446 \pm 0.426 \mathrm{~g}$, $\mathrm{n}=98$ vs $3.403 \pm 0.211 \mathrm{~g}, \mathrm{n}=97 \overline{1}$. There was no significant difference in protein, DNA and RNA contents between the fetuses from treated mothers and those from control mothers. This experiment confirms that oestrogens may play a role in fetal weight gain.

\section{Introduction.}

In the post-natal animal the major hormones stimulating growth are : growth hormone, thyroxine, insulin and the somatomedins. However, growth hormones have not been unequivocally shown to be associated with the growth of the fetus in utero (Jost, 1979 ; Spencer, 1986). The thyroid gland does appear to have an effect on fetal growth, but the effects vary according to the species (Jost, 1979).

Injections of oestradiol benzoate into pregnant rats cause a reduction in fetal growth (Kuhn, Bollen and Darras, 1982). In contrast, bilateral oophrectomy of pregnant rabbits results in an increase in fetal weight (Abdul-Karim et al., 1971). Thus maternal levels of oestrogens may be important in regulating fetal growth. In this paper we report the effect of immuno-neutralization of maternal plasma oestrogen levels on the growth of the fetal rat.

\section{Materials and methods.}

The experiments were performed with 14 pregnant Sprague-Dawley rats (seven treated and seven control). The morning on which a vaginal plug was noticed was considered to be day 1 of pregnancy. The rats were fed a standard

(1) Present address : Centre de recherches agricoles, St. Aubin (FR), CH-1566, Switzerland. 
laboratory diet and had free access to water and food ad libitum. On day 12 the treated animals were injected intraperitoneally with $2 \mathrm{ml}$ of an anti-oestradiol serum with a titre of $1: 200,000$. The titre of the antiserum is defined as that final dilution which binds $6 \mathrm{pg}$ of tritiated oestradiol when $6 \mathrm{pg}$ is $50 \pm 6 \%$ of the total (i.e. approximately $12 \mathrm{pg}$ ) added radioactive steroid. It can be calculated that this dose $(2 \mathrm{ml})$ should neutralize up to $2.4 \mu \mathrm{g}$ of oestradiol. The antiserum was raised in sheep against (17 $\beta$-oestradiol-6-carboxymethyloxime conjugated to ovalbumin as described elsewhere (Land et al., 1982). The antiserum showed $6-10 \%$ cross reaction with estrone, but no significant cross-reaction with other steroids. Control mothers were given $2 \mathrm{ml}$ of an antiserum raised in sheep against human serum globulin.

On day 21 the mothers were anaesthetised with an overdose of pentobarbitone sodium and the fetuses exposed by laparotomy and hysterotomy. The fetuses were delivered and weighed to an accuracy of $\pm 0.005 \mathrm{~g}$. The fetal placentas were also weighed. The fetuses were killed, immediately frozen in liquid nitrogen and then stored at $-30^{\circ} \mathrm{C}$.

Carcasses were later homogenised in water using a Silversson homogeniser and the content of DNA, RNA and protein in the homogenate were measured using standard methods (Abraham, Scaletta and Vaughan, 1972 ; Munro and Fleck, 1966 ; Wannemacher, Banks and Wunner, 1965).

\section{Results.}

Individual placental weights were significantly greater $(p<0.001)$ in the fetuses from the treated rats (table 1), and the mean placental weight for the treated litters was also significantly greater $(p<0.01)$ than the value for the control litters. The mean individual fetal weight $(p<0.05)$ was significantly greater in the fetuses from the treated mothers (table 1). This difference was also apparent when the mean litter weights $(p<0.05)$ was statistically analysed. There was no effect of immuno-neutralization of oestradiol on the number of fetuses per mother.

\section{TABLE 1}

The effect of administration of anti-oestradiol serum to maternal rats from day 12 of gestation, on individual fetal placental weights, fetal body weights, and on protein, DNA and RNA in the fetuses.

\begin{tabular}{|c|c|c|}
\hline & Control & Treated \\
\hline 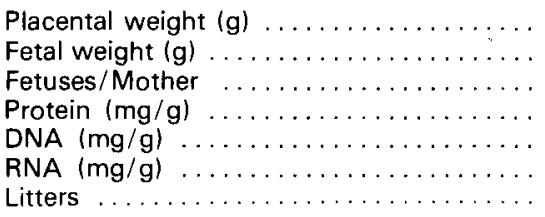 & $\begin{array}{l}0.742 \pm 0.019 \\
3.403 \pm 0.211 \\
13.84 \pm 0.71 \\
73.27 \pm 1.41 \\
2.704 \pm 0.115 \\
6.450 \pm 0.160\end{array}$ & $\begin{array}{l}0.851 \pm 0.023^{* * *} \\
4.446 \pm 0.426^{*} \\
13.96 \pm 0.55 \\
72.02 \pm 1.27 \\
2.485 \pm 0.100 \\
6.030 \pm 0.168\end{array}$ \\
\hline
\end{tabular}

Values are means \pm s.e.m. ; statistical significance determined by analysis of variance with $n=97$ for the controls and $n=98$ for the treated groups ; ${ }^{*} p<0.05 ;{ }^{* *} p<0.001$. 
There was no significant difference in the protein, DNA and RNA contents of the fetuses from treated mothers compared with those from the controls (table 1).

\section{Discussion.}

There are few data for a positive hormonal control of growth in the fetus. One of the most positive indications has been with gonadal steroids. Congenital virilising adrenal hyperplasia, is associated with an increased birth weight (Qazi and Thompson, 1971) and this is believed to be due to increased androgen levels. By contrast, increased levels of maternal oestradiol have been found to result in a reduction in fetal weight at birth (Kuhn, Bollen and Darras, 1982). Thus decreased maternal oestradiol levels may stimulate fetal growth.

Various possible methods might be employed to reduce the levels, or the effectiveness of oestrogens. Antagonists to oestrogen action may be used (Land and Scaramuzzi, 1979). However, they might produce compensatory overproduction of oestrogens or have inherent oestrogenic properties. Decreased oestrogen levels have also been produced by down-regulation of the $\mathrm{LH}$ stimulus for oestrogen production (Land, 1979) though this suffers from being an indirect approach which may be unpredictable in efficacy.

Reduced oestrogen levels can also be attained using antibodies to neutralise the oestrogens. Administration of oestrogen antiserum is an attractive option that requires minimal treatment of the animals. Furthermore, it enables all the treated animals to receive a uniform precalculated dose of antibodies.

It is not clear how this treatment affects fetal growth. It is doubtful that the antibodies would cross the placenta in sufficient quantity to directly affect fetal oestrogen levels or actions. There may, however, be reduced fetal plasma oestrogen levels as a result of decreased placental transfer of maternal oestrogen. There is also the possibility that the effect on growth of the placenta and fetus is a result of the decreased maternal oestrogen levels causing changes in the production of progesterone and oestradiol from the placenta, as has been demonstrated in the baboon (Castracana and Goldzieher, 1986). Furthermore, the role of placental lactogens in this phenomemon is unknown. Placental lactogens have been postulated as fetal growth promoting hormones and maternal oestrogens inhibit the secretion of placental lactogen in the rat (Robertson et al., 1984). Thus it is possible that immuno-neutralization of maternal oestrogen may stimulate fetal growth through elevated placental lactogen release.

The ability of the placenta to transfer nutritients to the fetus is of central importance. The efficiency of placental transfer is related to both the size of the placenta and the blood flow through the placenta. It is clear from the results of this study that placental size is increased following immuno-neutralization of oestrogen in the mother, but the effect on placental function remains to be established.

The findings reported here may have important practical application. It is well known that in multiple births the larger sibling usually exhibits more rapid growth post-natally (McKeown and Record, 1953; McKeown, Marshall and Record, 
1976). Whether the same is true when there is a general increase in size of the neonates in a litter is not known, but an increased size at birth may also be of help in diminuishing neonatal death.

In conclusion, immuno-neutralization of oestradiol levels in the pregnant rat is associated with an increase in weight of both the placenta and the fetus. This effect may be the result of subsequent changes in placental lactogen levels or, perhaps, direct effects of low oestrogen levels on cell responsiveness to other hormones such as somatomedins or placental blood flow, but no direct evidence is available to support either of these hypotheses.

Reçu en février 1986.

Accepté en septembre 1986.

Résumé. L'immuno-neutralisation de l'œstradiol plasmatique maternel stimule la croissance fotale chez le rat.

Au $12^{\mathrm{e}}$ jour de gestation, 7 rats ont reçu une quantité d'anticorps suffisante pour neutraliser $2,4 \mu \mathrm{g}$ d'œstradiol ; 7 autres rats témoins ont été injectés avec un antisérum dirigé contre la globuline sérique humaine. Au $21^{\mathrm{e}}$ jour de gestation les rats ont été sacrifiés. Les foetus des animaux traités montrèrent une augmentation des poids placentaire $(0,851 \pm 0,023 \mathrm{~g}, \mathrm{n}=98$ vs $0,752 \pm 0,019 \mathrm{~g}, \mathrm{n}=97 ; \mathrm{P}<0,001)$ et fœtal $(4,446 \pm 0,426 \mathrm{~g}, \mathrm{n}=98$ vs $3,403 \pm 0,211, \mathrm{n}=97 ; \mathrm{P}<0,05)$. Aucune différence statistique significative ne fut observée concernant l'ADN, I'ARN et les protéines corporelles totales. Ces résultats indiquent que les œestrogènes maternels peuvent jouer un rôle dans le développement du fœetus.

\section{References}

ABDUL-KARIM R. W., NESBITT R. E. L., DRUCKER M. H., RISK P. T., 1971. The regulatory effect of estrogens on fetal growth. 1. Placental and fetal body weights. Am. J. Obstet. Gynecol., 109, 656-661.

ABRAHAM G. N., SCALETTA C., VAUGHAN J. A., 1972. Modified diphenylamine reaction for increased sensitivity. Anal. Biochem., 49, 547-549.

CASTRACANA V. D., GOLDZIEHER J. W., 1986. The relationship of estrogen to placental steroidogenesis in the baboon. J. clin. Endocr. Metab., 62, 1163-1166.

JOST A., 1979. Fetal hormones and fetal growth, 1-20. In T. ZONDEK, L. H. ZONDEK, Fetal endocrinology, Karger, Basel.

KUHN E. R., BOLLEN M., DARRAS V., 1982. Fetal growth inhibition and decreased thyroid activity after injection of oestradiol benzoate into pregnant rats. J. Endocrinol., 93, 55-63.

LAND R. B., 1979. Improvement in gonadal function through modification of negative feedback. Ann. Biol. anim. Biochim. Biophys., 19, 1569-1574.

LAND R. B., SCARAMUZZI R. J., 1979. A note on the ovulation rate of sheep following treatment with clomiphene citrate. Anim. Prod., 28, 131-134.

LAND R. B., MORRIS B. A., BAXTER G., FORDYCE M., FORSTER J., 1982. Improvement of sheep fecundity by treatment with antisera to gonadal steroids. J. Reprod. Fert., 66, 625-634.

MCKEOWN T., RECORD R. G., 1953. The influence of placental size on foetal growth in man, with special reference to multiple pregnancy. J. Endocrinol., 9, 418-426.

McKEOWN T., MARSHALL T., RECORD R. G., 1976. Influences on growth. J. Reprod. Fert., 47, 167-181.

MUNRO H. N., FLECK A., 1966. The determination of nucleic acids. Methods Biochem. Anal., 14, 113-176. 
ROBERTSON M. C., OWENS R. E., McCOSHEN J. A., FRIESEN, H. G., 1984. Ovarian factors inhibit and fetal factors stimulate the secretion of rat placental lactogen. Endocrinology, 114, 22-30.

SPENCER G. S. G., 1986. Hormonal influences on fetal growth, 1205-1213. In M. E. TUMBLESON, Swine in biomedical research. Vol. 2. Plenum, New York.

QAZI O. H., THOMPSON M. W., 1971. Birth weight in congenital virilising adrenal hyperplasia. Arch. Dis. Childhd., 46, 350-352.

WANNEMACHER R. W., BANKS W. L., WUNNER W. H., 1965. Use of a single tissue extract to determine cellular protein and nucleic acid concentrations and rate of amino acid incorporation. Anal. Biochem., 11, 320-326. 